\title{
The Increase of Parathyroid Hormone-Related Peptide and Cytokine Levels in Synovial Fluid of Elderly Rheumatoid Arthritis and Osteoarthritis
}

\author{
TOSHIYUKI HORIUCHI, TSUYOSHI YOSHIDA*, YASUKo KOSHIHARA*, HIROSHI SAKAMOTO, \\ HIROYUKI KANAI**, SEIZo YAMAMOTO** AND HIDEKI ITO \\ Department of Endocrinology, Tokyo Metropolitan Geriatric Hospital, Tokyo 173-0015, Japan \\ * Department of Nutrition, Tokyo Metropolitan Institute of Gerontology, 35-2 Sakae-cho Itabashi-ku, Tokyo 173-0015, Japan \\ ** Department of Orthopedics, Tokyo Metropolitan Geriatric Hospital, Tokyo 173-0015, Japan
}

\begin{abstract}
We simultaneously measured the concentrations of parathyroid hormone related peptide (PTHrP) and cytokines in synovial fluid (SF) to clarify the relationship between PTHrP and cytokine network in the SF of elderly patients with arthritis. SF was collected from knee joints of five RA patients aged $66 \pm 11$ years old and nine osteoarthritis (OA) patients aged $80 \pm 9$ years old. PTHrP in SF was measured by enzyme-linked immunosorbent assay (ELISA), whereas tumor necrosis factor- $\alpha$ (TNF- $\alpha$ ), interleukin-1 $\beta$ (IL-1 $\beta$ ), interleukin-2 (IL-2), interleukin-4 (IL-4), interleukin-6 (IL-6) and interleukin-8 (IL-8) in SF were all measured by ELISA. The PTHrP levels in the SF of RA patients $(2.56 \pm 0.89 \mathrm{pmol} / \mathrm{l})$ were significantly $(\mathrm{p}<0.05)$ higher than those of OA patients $(1.66 \pm 0.17 \mathrm{pmol} / \mathrm{l})$. TNF- $\alpha$, IL-1 $\beta$, IL-2 and IL-6 concentrations in SF of RA were also significantly higher than those in SF of OA (TNF- $\alpha 22.5 \pm 14.8$ vs $4.8 \pm 3.0 \mathrm{pg} / \mathrm{ml}, \mathrm{p}<0.01$; IL-1 $\beta 11.8 \pm 11.4$ vs $1.4 \pm 1.3, \mathrm{p}<0.05$; IL-2 $59.9 \pm 46.6$ vs $12.5 \pm 8.0 \mathrm{pg} / \mathrm{ml}, \mathrm{p}<0.05$; IL-6 $18424 \pm 8901 \mathrm{vs} 3547 \pm 2948 \mathrm{pg} / \mathrm{ml}, \mathrm{p}<0.01)$. The concentrations of IL-4 and IL-8 in SF of RA were similar to those of OA. Immunohistochemical studies revealed the presence of immunoreactive PTHrP in synovial fibroblasts from RA and OA. Among cytokines, only IL-6 was positively correlated with PTHrP levels in $\mathrm{SF}(\mathrm{r}=0.685, \mathrm{p}<0.01)$. In the culture of synovial cells from RA and OA, PTHrP was produced in RA more than OA after phorbol 12-mysistate 13-acetate (TPA) stimulation. These results indicate that PTHrP and cytokines, especially IL-6, might be involved in the inflammatory processes of elderly RA and OA. This is the first study in which PTHrP and cytokine levels were simultaneously examined in synovial fluid of elderly RA and OA.
\end{abstract}

Key words: Parathyroid hormone-related peptide, Cytokines, Synovial fibroblast, Elderly rheumatoid arthritis, Elderly osteoarthritis

(Endocrine Journal 46: 643-649)

PARATHYROID hormone related peptide (PTHrP) is well known to be expressed in solid cancers such as lung squamous carcinoma which causes hypercalcemia [1], whereas PTHrP is widely distributed in adult normal tissues and regulates the proliferation and differentiation of epithelial and mesenchymal cells [2]

Received: November 13, 1998

Accepted: April 20, 1999

Correspondence to: Dr. Toshiyuki HORIUCHI, Department of Endocrinology, Tokyo Metropolitan Geriatric Hospital, Tokyo 173-0015, Japan as well as the relaxation of vessels in the physiological condition [3]. Recently PTHrP has been shown to be expressed in rat articular cartilage and synovial cells in rheumatoid arthritis (RA) and osteoarthritis (OA) [4] and is also expressed in articular chondrocytes on the upper surface of normal rat articular cartilage [5].

In addition to the effect of cell differentiation and calciotrophic action, PTHrP might be associated with cytokine-mediated host defence against infection and inflammation [6]. Moreover regulation of PTHrP mRNA by cytokines was demonstrated in mouse 
spleen indicating the counterbalancing effects by either infection or inflammation [7]. Therefore it is possible to assume that PTHrP secreted by articular cartilage or synovial cells play a role in the inflammatory process of RA.

PTHrP was identified in the synovial fluid (SF) of RA and OA in women and men over sixty years old [4]. Cyclic adenosine monophosphate accumulation in SF has been reported by another group[8], suggesting that PTHrP is involved in joint inflammation. Several cytokines such as tumor necrosis factor- $\alpha$ (TNF- $\alpha$ ), interleukin-1 $\beta$ (IL-1 $\beta$ ) and interleukin-6 (IL-6) might play some roles in the cartilage degradation through the activation of synovial fibroblasts in RA and OA[9]. However, the interaction of PTHrP and cytokines in the inflammatory processes of RA and OA remains to be elucidated. In order to clarify the pathogenesis of synovitis in elderly RA and OA, we measured PTHrP levels and concentrations of TNF- $\alpha$, IL-1 $\beta$, interleukin-2 (IL-2), interleukin-4 (IL-4), IL-6 and interleukin-8 (IL-8) in SF. We also confirmed the types of cells which produced PTHrP in the synovium after synovial cells were cultured.

\section{Materials and Methods}

\section{Patients}

Five RA patients (three women and two men; average age, $66 \pm 11$ years) were diagnosed on the basis of criteria of the American Rheumatology Association. Nine OA patients (nine women; average ages, $80 \pm 9$ years) were also diagnosed on the basis of radiographic findings, including narrowing of joint space and sclerotic change. Synovial tissues were obtained at surgical knee joint operation with informed consent.

\section{Synovial fibroblasts in culture}

Synovial fibroblasts were cultured according to the methods reported by Yoshida et al. [10]. Briefly synovia obtained from knee joint synovectomy were dissected and washed twice by RPMI 1640 (Gibco BRL, MD, USA), and finely minced with scissors. The minced tissues were incubated in RPMI 1640 containing $1 \mathrm{mg} / \mathrm{ml}$ collagenase (Wako Pure
Chemicals, Osaka, Japan) and $0.15 \mathrm{mg} / \mathrm{ml}$ DNase I (Sigma, St. Louis, MO, USA) and incubated with shaking for $90 \mathrm{~min}$ at $37^{\circ} \mathrm{C}$. The cell suspensions were filtered through a $70 \mu \mathrm{m}$ cell strainer (BectonDickinson, Franklin Lakes, NJ). For separation the synovial fibroblasts, the cell suspensions were layered on $4 \mathrm{ml}$ of Ficoll/Paque (Pharmacia Biotech, Uppsala, Sweden) and centrifuged at $400 \times \mathrm{g}$ for $30 \mathrm{~min}$ at $20^{\circ} \mathrm{C}$. Cells in the interface layer were collected and seeded in culture dishes after washing three times with RPMI 1640. The collected cells were cultured in $\alpha$-MEM supplemented with $20 \%$ horse serum at $37^{\circ} \mathrm{C}$ under $\mathrm{CO}_{2}$ in air. In order to determine the amount of PTHrP produced by the fibroblasts, the synovial fibroblasts at 7-10 population doubling levels (PDL) were treated with trypsin/EDTA solution for $5 \mathrm{~min}$ to detach them from dishes and collected by centrifugation at $250 \times \mathrm{g}$ for $10 \mathrm{~min}$. The detached cells were plated onto 12-well multi-well dishes at $10^{5}$ cells/well with $1.0 \mathrm{ml}$ of $\alpha$-MEM containing $20 \%$ horse serum. Confluent synovial fibroblasts were incubated with $10 \mathrm{nM}$ of phorbol 12-mysistate 13acetate (TPA) for 24 hours after replacement of culture medium with $\alpha$-MEM supplemented with 5\% horse serum. The PTHrP levels in the conditioned medium were measured directly by IRMA. The amount of DNA in each well was measured after extraction with hot $5 \%$ perchloric acid.

\section{Immunohistochemistry}

Immediately after the RA and OA patients had been operated on for plate replacement, obtained synovia were fixed with $10 \%$ of formalin in neutral phosphate buffer and embedded in paraffin. The paraffin block was sliced into thin sections. After deparaffinization and rehydration, the synovial preparation was incubated for $\mathbf{3 0}$ minutes at room temperature with diluted monoclonal antibody against human 1-34 PTHrP or polyclonal antibody against human 45-59 PTHrP commercially obtained (Cosmo-Bio Co., Tokyo). Immunostainings were completed with stravidin-biotin method using LSAB Kit (DAKO Corporation, CA USA ). The preparation incubated without PTHrP antibody served as the control. 
Immunoradiometric assay (IRMA) and Enzymelinked immunosorbent assay (ELISA)

SF was collected by arthrocenthesis from knee joints, immediately transferred to the tube containing aprotinin and EDTA (Terumo Co.,Tokyo, JAPAN) and frozen at $-70^{\circ} \mathrm{C}$ until assay. Immunoradiometric assay of PTHrP was done by the two-site IRMA method (Allegro PTHrP, Nichols Institute Diagnostics, San Juan Capistrano, CA, USA ). The two-site IRMA method was performed with ${ }^{125}$ Ipolyclonal antibody to N-terminal residues (1-40) of human PTHrP and with biotin-polyclonal antibody to C-terminal residues (60-72) of human PTHrP by adding avidin-coated beads. The minimum detectable levels in this assay was $0.2 \mathrm{pmol} / \mathrm{l}$. Intraassay and interassay variance of PTHrP was 3.4-5.8\% and $4.0-7.5 \%$, respectively. The concentrations in synovial fluids of TNF- $\alpha$, IL-1 $\beta$, IL-2, IL-4, IL-6 and IL-8 were determined by ELISA (R \& D Systems, Minneapolis, MN, USA). Intraassay and interassay

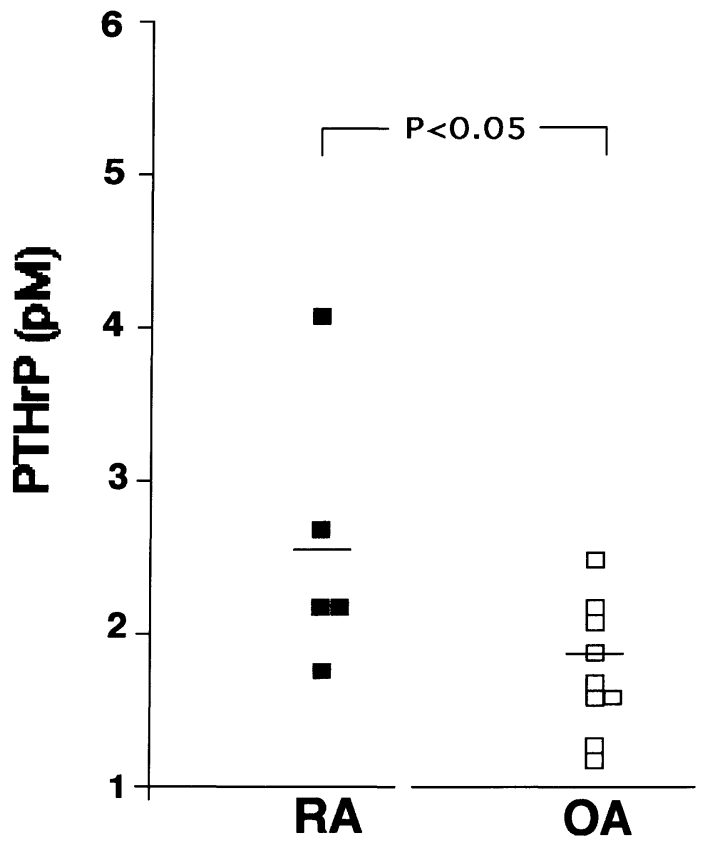

Fig. 1. Immunoradiometric assay of PTHrP levels in synovial fluids of RA and OA. Concentrations of PTHrP in five RA patients (average age, 66 years; $\square$ ) and nine OA patients (average age, 80 years; $\square$ ) were $3.0 \pm 1.4$ and $1.8 \pm 0.2 \mathrm{pmol} / 1$, respectively. PTHrP value in RA was significantly higher than in $O A$ $(p=0.026)$. variances of these cytokines measurements were $5.7 \%$ and $7.8 \%$ for TNF- $\alpha, 4.2 \%$ and $4.8 \%$ for IL$1 \beta, 6.1 \%$ and $8.9 \%$ for IL-2, $2.7 \%$ and $4.5 \%$ for IL-4, 3.8\% and $7.1 \%$ for IL-6, and $5.5 \%$ and $2.6 \%$ for IL-8, respectively.

\section{Statistical analysis}

All values from experiments were calculated and analyzed with an SPSS program. All values were expressed as the mean \pm SD. Student's t-test and a simple regression were used for statistical analysis.

\section{Results}

\section{IRMA of PTHrP levels in synovial fluids}

The PTHrP levels in SF in RA and OA are plotted in Fig. 1. The average concentration of PTHrP in five RA patients was higher than that in nine OA patients $(2.6 \pm 0.9$ vs $1.8 \pm 0.2 \mathrm{pmol} / 1, \mathrm{p}=0.006)$. The highest PTHrP (4.1 pM) value was found in a 62 year old female RA patient.

\section{Measurements of cytokine concentrations in SF}

The average concentrations of each cytokine in five RA and nine OA patients are shown in Table 1. The concentrations of TNF- $\alpha$, IL-2 and IL-6 in synovial

Table 1. Measurements of cytokines concentrations in SF

\begin{tabular}{|c|c|c|c|}
\hline Cytokine & RA & $\mathrm{OA}$ & P-value \\
\hline $\begin{array}{l}\text { TNF- } \alpha \\
(\mathrm{pg} / \mathrm{ml})\end{array}$ & $19.5 \pm 15.1$ & $4.8 \pm 3.0$ & $0.018^{*}$ \\
\hline $\begin{array}{l}\text { IL-1 } \beta \\
(\mathrm{pg} / \mathrm{ml})\end{array}$ & $9.9 \pm 11.3$ & $1.4 \pm 1.3$ & 0.053 \\
\hline $\begin{array}{l}\text { IL-2 } \\
(\mathrm{pg} / \mathrm{ml})\end{array}$ & $85.2 \pm 94.4$ & $12.5 \pm 8.0$ & $0.047^{*}$ \\
\hline $\begin{array}{l}\text { IL-4 } \\
(\mathrm{pg} / \mathrm{ml})\end{array}$ & $1.4 \pm 1.9$ & $1.4 \pm 1.7$ & 0.076 \\
\hline $\begin{array}{l}\text { IL-6 } \\
\text { (pg/ml) }\end{array}$ & $15993 \pm 9941$ & $3547 \pm 2948$ & $0.005^{* *}$ \\
\hline $\begin{array}{l}\text { IL-8 } \\
(\mathrm{pg} / \mathrm{ml})\end{array}$ & $21872 \pm 36788$ & $1060 \pm 1781$ & 0.13 \\
\hline
\end{tabular}

Plasma levels of six cytokines are demonstrated as mean $\pm S D$. All values are from five RA patients and nine OA patients. Statistical analyses were performed with ANOVA and Student's t-test. ${ }^{*}: \mathrm{p}<0.05{ }^{* *}: \mathrm{p}<0.01$. 
fluids of RA were significantly higher than those of OA. Although the difference was not statistically significant, the levels of IL- $1 \beta$ and IL-8 in synovial fluid of RA were modestly higher than in OA. IL-4 level in synovial fluid was as high as the normal plasma level.

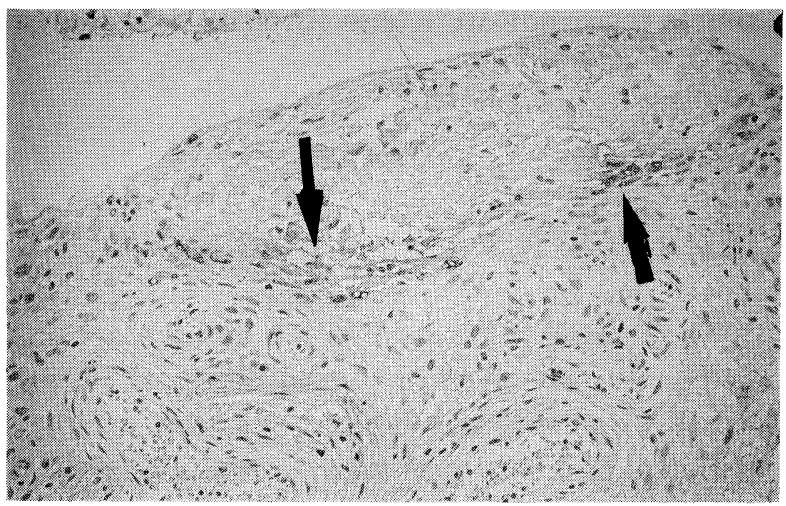

RA

a

\section{Localization of PTHrP by immunohistochemistry}

Immunohistochemical studies revealed the presence of immunoreactive PTHrP in fibroblasts of the synovium. Positive stainings were entirely detected in sublining regions in the synovium of RA (Fig. 2a). Microscopically the cell shape was spindle-like. In OA, PTHrP positive stainings

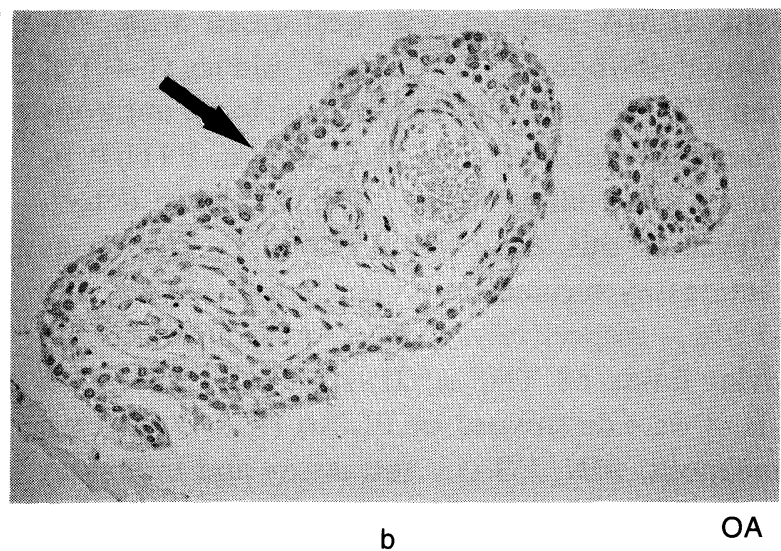

Fig. 2. Localization of PTHrP by immunohistochemistry. On the left PTHrP expression on fibroblasts in a RA patient is indicated by arrows $(\times 120,2 a)$. Similarly, on the right is shown the positive stainings of PTHrP expression on fibroblasts in a OA patient $(\times 240,2 b)$.

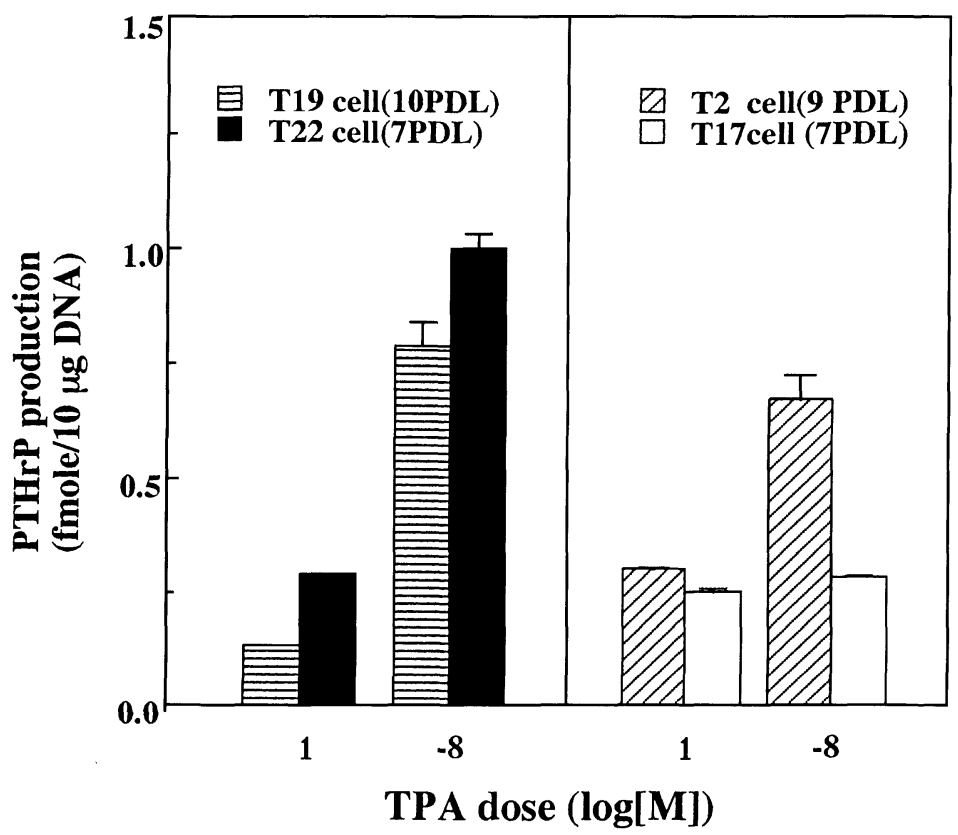

Fig. 3. PTHrP production by synovial fibroblasts in culture in the presence or absence of TPA. T19 and T22 cells are fibroblasts cultured from RA patients, and T2 and T17 cells are from OA patients. 


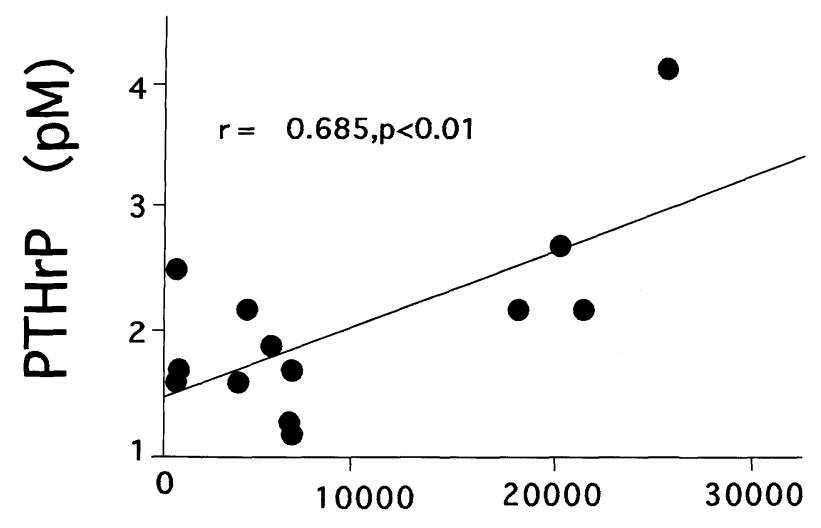

IL-6 (pg/ml)

Fig. 4. Simple regression between PTHrP and IL-6. The PTHrP level in SF was positively correlated with the IL-6 level with correlation coefficient of 0.685 and $p$ value of 0.008 in statistical analysis.

were detected only in fibroblasts on the first layer of the synovium preparation (Fig. 2b).

\section{PTHrP production by fibroblasts from synovium}

The fibroblasts were prepared from the synovium of two RA patients and two OA patients and cultured. The fibroblast phenotype was stable in culture through seven to ten PDL. The levels of PTHrP in the culture medium were measured by IRMA with $200 \mu \mathrm{l}$ of the medium. As shown in Fig. 3, TPA $(10 \mathrm{nM})$ increased the production of PTHrP from $0.1 \mathrm{fmole} / 10 \mu \mathrm{g}$ DNA to 0.8 or $1.0 \mathrm{fmole} / 10 \mu \mathrm{g}$ DNA in RA and 0.3 to $0.7 \mathrm{fmole} / 10 \mu \mathrm{g}$ DNA in OA fibroblasts.

\section{Correlations between PTHrP levels and cytokine levels}

PTHrP concentrations in SF were positively correlated with IL-6 $(r=0.685, \mathrm{p}<0.01)$ (Fig. 4). No cytokines other than IL-6 were significantly correlated with PTHrP in simple regression analyses.

\section{Discussion}

Our results concerning PTHrP levels in SF were consistent with previous reports $[4,8,11]$ which demonstrated high concentrations of PTHrP in SF of elderly RA and OA despite aging. Ages of our patients were a little older than those previously reported $[4,8]$. Immunohistochemical studies also showed the presence of PTHrP in fibroblasts in the synovium.

Ordinally plasma PTHrP concentration is low in normal adult unless suffering from cancer. High levels of PTHrP has been demonstrated only in milk of postpartum lactating women [12]. In our study, PTHrP concentrations in SF of RA patients were extremely high in a 62-year-old patient in this study. In spite of old age, PTHrP was abundantly and locally expressed in RA and OA synovial fibroblasts in inflammatory conditions as well as in malignant tumors. These elderly RA and OA patients were not suffering from cancer such as squamous cell carcinoma of the lung or adult T-cell leukemia [13]. Plasma PTHrP concentrations were within the normal range (data not shown) in fourteen patients. PTHrP seems to be locally working in an autocrine or paracrine factor mediated through cytokines in synovitis of elderly RA or OA patients. The importance of IL-1 $\beta$, TNF- $\alpha$ and IL- 6 has already been discussed in connection with inflammatory synovitis [14]. TNF- $\alpha$, IL-2 and IL-6 concentrations in RA synovial fluids were significantly higher than that in SF of OA. IL- $1 \beta$ concentration in RA was as high as those in $\mathrm{OA}$, but the trend was higher in RA. Alternatively IL-2 levels in SF of RA were higher than in OA. There was no evidence of a simultaneous action of PTHrP and cytokines on synovitis, nor was there any indication of how PTHrP plays a part with cytokine in this process, although concomitant increases in both PTHrP and cytokines levels were seen in our study.

Although the role of PTHrP in synovitis is unknown, the action of cytokines in synovitis has already been reported [14]. Contact between fibroblasts and cartilage is necessary for cartilage destruction. Cartilage destruction by synovial fibroblasts was inhibited by antibodies to TNF- $\alpha$, IL-1 $\beta$ and IL-6, suggesting that soluble factors such as cytokines are essential for cartilage destruction. Cytokines are released from either macrophages [14] or fibroblasts [10] and possibly stimulate the release of PTHrP from synovium subsequently, since IL- $1 \alpha$, IL-1 $\beta$ and IL-6 induced PTHrP production into the cultured medium of synovial fibroblasts [10]. 
PTHrP induced by TNF- $\alpha$, IL-1 $\beta$ or IL-6, in turn, might be involved in the cell proliferation of synovium, since PTHrP is important for cell growth and differntiation [2]. Macroscopic findings of surgically resected RA synovia in our patients were thicker than in OA (data not shown), suggesting that PTHrP activates synovial proliferation. In order to examine the action of synovial cell growth by PTHrP we must further study the thymidine incorporation by $\mathrm{PTHrP}$ into synovial fibroblast in RA patients.

Whether PTHrP causes joint destruction by inducing osteoclasts in arthral tissue or not is still unknown. We were not able to detect osteoclasts microscopically in synovial tissue sections. From the point of view that PTHrP concentrations in SF were extremely high, PTHrP appears to stimulate remote osteoblasts with PTH/PTHrP receptor and induce osteoclasts in the articular tissue [15]. Consequently joint destruction might be caused through osteoclastogenesis by PTHrP. Our report suggests that it might be possible to detect osteoclasts using phenotype markers such as calcitonin receptor in articular tissue [16].

Physiologically PTHrP is involved in the cartilage maturation of neonatal rat, since PTHrP-deficient rat displayed abnormal development of cartilage [17]. PTHrP acts locally on chondrocytes and delays chondrocyte differentiation because of proliferation of chondrocytes [18]. The origin of PTHrP in arthritis tissue is regarded as either fibroblasts in pannus of RA [8] or in chondrocytes of OA [4], since the precise type of cell producing PTHrP in arthritis had yet to be clarified. Our study using synovial cell culture system showed that PTHrP is released into culture medium by fibroblasts from either elderly RA or OA synovium. There was no contamination of chondrocytes in our system.

In summary, PTHrP and cytokine levels in synovial fluid were measured in elderly RA and OA. PTHrP, TNF- $\alpha$, IL-2 and IL-6 levels in SF of elderly RA were higher than those in elderly OA. Particularly, there was a positive correlation between PTHrP and IL-6 production in RA and OA knee joints, indicating PTHrP was being produced by cultured synovial fibroblasts from RA and OA patients. Our results suggested that PTHrP and cytokines may be involved in the synovitis of elderly RA and OA patients.

\section{Acknowledgements}

We thank Katsumi Arai for his excellent technical assistance in the immunohistochemistry protein work of our study.

\section{References}

1. Mosely JM, Kubota M, Diefenback-Jagger $\mathrm{H}$, Wettenhall REH, Suva LJ, Rodda CP, Ebeling PR, Hudson PJ, Zajac JD, Martin TJ (1987) Parathyroid hormone-related protein purified from a human lung cancer cell line. Proc Natl Acad Sci USA 84: 1803-1807.

2. de Papp AE, Stewart AF (1993) Parathyroid hormone-related protein: a peptide of diverse physiologic functions. Trends Endocrinol Metab 4: 181-187.

3. Yamamoto M, Harm SC, Grasser WA, Thiede MA (1992) Parathyroid hormone related protein in rat urinary bladder: a smooth muscle relaxant produced in response to mechanical stretch. Proc Natl Acad Sci USA 89: 5326-5330.

4. Okano K, Tsukazaki T, Ohtsuru A, Namba H, Osaki M, Iwasaki K, Yamashita S (1996) Parathyroid hormone-related peptide in synovial fluid and disease activity of rheumatoid arthritis. $\mathrm{Br} \mathrm{J}$ Rheum 35:
1056-1062.

5. Tsukazaki T, Ohtsuru A, Enomoto H, Yano H, Motomura $\mathrm{K}$, Ito $\mathrm{M}$, Namba $\mathrm{H}$, Iwasaki $\mathrm{K}$, Yamashita S (1995) Expression of parathyroid hormone-related protein in rat articular cartilage. Calcif Tissue Int 57: 196-200.

6. Funk JL, Moser AH, Grunfeld C, Feingold KR (1997) Parathyroid hormone-related protein is induced in the adult liver during endotoxemia and stimulates the hepatic acute phase response. Endocrinology 138: 2665-2673.

7. Funk JL, Shigenaga JK, Moser AH, Krul EJT, Strewler GJ, Feingold KR, Grunfeld C (1994) Cytokine regulation of parathyroid hormone-related protein messenger ribonucleic acid levels in mouse spleen: Paradoxical effects of interferon- $\gamma$ and interleukin-4. Endocrinology 135: 351-358.

8. Kohno H, Shigeno C, Kasai R, Akiyama H, Iida H, 
Tsuboyama T, Sato K, Konishi J, Nakamura T (1997) Synovial fluids from patients with osteoarthritis and rheumatoid arthritis contain high levels of parathyroid hormone-related peptide. J Bone Miner Res 12: 847-854.

9. Chin JE, Winterrowd G, Krzesicki RF, Sanders ME (1990) Role of cytokines in inflammatory synovitis. Arthritis Rheum 33: 1776-1786.

10. Yoshida $T$, Horiuchi $T$, Sakamoto $H$, Inoue $H$, Takayanagi H, Nishikawa T, Yamamoto S, Koshihara Y (1998) Production of parathyroid hormonerelated peptide by synovial fibroblasts in human osteoarthritis. FEBS Lett 433: 331-334.

11. Okano K, Tsukazaki T, Ohtsuru A, Osaki M, Yonekura A, Iwasaki K, Yamashita S (1997) Expression of parathyroid hormone-related peptide in human osteoarthritis. J Orthop Res 15: 175-180.

12. Budayr AA, Halloran BP, King JC, Diep D, Nissenson RA, Strewler GJ (1989) High levels of a parathyroid hormone-like protein in milk. Proc Natl Acad Sci USA 86: 7183-7185.

13. Fukumoto $\mathrm{S}$, Matsumoto $\mathrm{T}$, Watanabe $\mathrm{T}$, Takahashi H, Miyoshi I, Ogata E (1989) Secretion of parathyroid hormone-like activity from human T-cell lymphotropic virus type I-infected lymphocytes.
Cancer Res 49: 3849-3852.

14. Scott BB,Weisbrot LM, Greenwood JD, Bogoch ER, Paige CJ, Keystone EC (1997) Rheumatoid arthritis synovial fibroblast and U937 macrophage/monocyte cell line interaction in cartilage degradation. Arthritis Rheum 40: 490-498.

15. Suda T, Udagawa N, Nakamura I, Miyaura C, Takahashi N (1995) Modulation of osteoclast differentiation by local factors. Bone 17: 87S-91S.

16. Lee SK, Goldring SR, Lorenzo JA (1995) Expression of the calcitonin receptor in bone marrow cell cultures and in bone: a specific marker of the differentiated osteoclast that is regulated by calcitonin. Endocrinology 136: 4572-4581.

17. Karaplis AC, Luz A, Glowacki J, Bronson RT, Tybulewicz VLJ, Kronenberg HM, Mulligan RC (1994) Lethal skeltal dysplasia from targeted disruption of the parathyroid hormone-related peptide gene. Genes Dev 8: 277-289.

18. Lanske B, Karaplis AC, Lee K, Luz A, Vortkamp A, Pirro A, Karperien M, Defize LHK, Ho C, Mulligan RC, Abou-Samra AB, Juppner H, Segre G, Kronenberg HM (1996) PTH/PTHrP receptor in early development and Indian hedgehog-regulated bone growth. Science 273: 663-666 